\title{
A new method for the synthesis of diamantane by hydroisomerization of binor-S on treatment with sulfuric acid
}

\author{
Rishat I. Aminov* and Ravil I. Khusnutdinov
}

\author{
Full Research Paper \\ Address: \\ Institute of Petrochemistry and Catalysis, Russian Academy of \\ Sciences, pr. Oktyabrya 141, Ufa, 450075, Russian Federation \\ Email: \\ Rishat I. Aminov* - rishaminov@gmail.com \\ ${ }^{*}$ Corresponding author \\ Keywords: \\ binor-S; diamantane; hydroisomerization; sulfuric acid; \\ tetrahydrobinor-S
}

Open
Beilstein J. Org. Chem. 2020, 16, 2534-2539.
https://doi.org/10.3762/bjoc.16.205
Received: 25 July 2020
Accepted: 01 October 2020
Published: 12 October 2020
Associate Editor: H. Ritter
(C) 2020 Aminov and Khusnutdinov; licensee Beilstein-Institut.
License and terms: see end of document.

\section{Abstract}

A new method was developed for the direct synthesis of the second representative of the homologous series of diamondlike hydrocarbons, diamantane, in $65 \%$ yield by hydroisomerization of the norbornadiene dimer, endo-endoheptacyclo[8.4.0.0 $\left.0^{2,12} \cdot 0^{3,8} \cdot 0^{4,6} \cdot 0^{5,9} \cdot 0^{11,13}\right]$ tetradecane (binor-S) on treatment with concentrated sulfuric acid (98\%). In the presence of $\mathrm{H}_{2} \mathrm{SO}_{4}$ of lower concentration $(75-80 \%)$, the reaction stops after the hydrogenation step giving endo-endopentacyclo[7.3.1.1 $\left.1^{2,5} \cdot 1^{8,10} \cdot 0^{3,7}\right]$ tetradecane in $68 \%$ yield with excellent selectivity $(100 \%)$.

\section{Introduction}

Among the highly diverse polycyclic and cage compounds, an important place is occupied by diamond-like compounds called diamondoids, whose lower representatives belong to the homologous series $\mathrm{C}_{4 n+6} \mathrm{H}_{4 n+12}$. Owing to the rigid structure, diamondoids typically have high thermal stability and high reactivity compared with aliphatic and alicyclic saturated hydrocarbons and show peculiar chemical behavior.

Crude oil is known to be the main natural source of diamondoids. In the oil and gas field exploration, the presence of diamondoids is used to evaluate the field maturity. Whereas the synthesis and chemical reactivity of adamantane, the first member of the diamondoid homologous series, which is pro- duced on an industrial scale (prepared by $\mathrm{AlBr}_{3}$ or $\mathrm{AlCl}_{3}$-induced skeletal isomerization of a petrochemical monomer, hydrogenated dicyclopentadiene) [1], have been studied rather extensively, the chemical behavior of diamantane, the second member of the diamandoid homologous series, has been poorly studied. The main cause of this situation is the lack of facile methods for its synthesis.

In the literature, diamantane (1) is prepared by skeletal isomerization of strained $\mathrm{C}_{14} \mathrm{H}_{20}$ polycyclic hydrocarbons [2-7]. In particular, the most suitable initial compounds for the preparation of diamantane are three isomeric polycyclic hydrocarbons $\mathrm{C}_{14} \mathrm{H}_{20} \mathbf{3 a}$-ce, which are obtained 
by hydrogenation of the norbornadiene dimer, heptacyclo[8.4.0.0 $\left.0^{2,12} \cdot 0^{3,8} \cdot 0^{4,6} \cdot 0^{5,9} \cdot 0^{11,13}\right]$ tetradecane (binor-S, 2). Binor-S is hydrogenated in the presence of a platinum catalyst $\left(\mathrm{H}_{2} \mathrm{PtCl}_{6}, \mathrm{PtO}_{2}\right)$ in glacial acetic acid under high pressure conditions at $70{ }^{\circ} \mathrm{C}$ and $200 \mathrm{psi}$ of $\mathrm{H}_{2}$ [8,9]. In the presence of superacid catalysts, such as $\mathrm{B}\left(\mathrm{OSO}_{2} \mathrm{CF}_{3}\right)_{3}, \mathrm{CF}_{3} \mathrm{SO}_{3} \mathrm{H} / \mathrm{SbF}_{5}$ 1:1, $\mathrm{CF}_{3} \mathrm{SO}_{3} \mathrm{H} / \mathrm{B}\left(\mathrm{OSO}_{2} \mathrm{CF}_{3}\right)_{3}$ 1:1 [10], $\mathrm{NaBH}_{4} / \mathrm{CF}_{3} \mathrm{SO}_{3} \mathrm{H}$ [11], or zeolite $\mathrm{Y}$ in the $\mathrm{NaH}$ form (NaY) [12], hydrocarbons 3a-c isomerize to diamantane in up to $99 \%$ yield (Scheme 1).

As can be seen from Scheme 1, the synthesis of diamantane (1) from binor-S (2) is a two-step process, in which the hydrogenation performed in the first step is most complex and has always been an obstacle to the generation of large amounts of diamantane. In view of the foregoing, we set ourselves the task to develop a one-pot method for the synthesis of diamantane (1) from binor-S (2).

\section{Results and Discussion}

In this study, we developed a new method for the synthesis of pentacyclo[7.3.1.1 $\left.1^{4,12} \cdot 0^{2,7} \cdot 0^{6,11}\right]$ tetradecane (diamantane, $\mathbf{1}$ ) by skeletal hydroisomerization of endo-endo-heptacyclo[8.4.0.0 $\left.0^{2,12} \cdot 0^{3,8} \cdot 0^{4,6} \cdot 0^{5,9} \cdot 0^{11,13}\right]$ tetradecane (binor-S, 2) on treatment with sulfuric acid (Scheme 2).

The reaction selectivity and the yield of diamantane (1) considerably depend on the reaction conditions and the solvent nature. Indeed, at $20-40{ }^{\circ} \mathrm{C}$, hydroizomerization of binor-S (2) in cyclohexane in the presence of $98 \%$ sulfuric acid $\left([2] /\left[\mathrm{H}_{2} \mathrm{SO}_{4}\right]=1: 10-50\right)$ during $7-15 \mathrm{~h}$ affords a mixture of endo-endo-pentacyclo[7.3.1.1 $\left.1^{2,5} \cdot 1^{8,10}\right]$ tetradecane (tetrahydrobinor-S, 3c) and diamantane (1) (Table 1). An increase in the sulfuric acid ratio to binor-S (2) $\left([2] /\left[\mathrm{H}_{2} \mathrm{SO}_{4}\right]=1: 20-50\right)$ and rising the temperature to $40{ }^{\circ} \mathrm{C}$ lead to decreased product yield due to resinification. When the $\mathrm{H}_{2} \mathrm{SO}_{4}$ ratio to binor-S (2) is $1: 5$, the conversion of compound 2 decreases to $10 \%$. On the other hand, when the reactions are carried out in $\mathrm{CS}_{2}$ or without any solvent, the selectivity to diamantane (1) increases to $100 \%$, with the maximum yield being $65 \%$ (Table 1 , entry 12 ). A portion of binor-S (2) is converted to resinous products. When the reaction was ultrasonically assisted, the reaction time decreased to $2 \mathrm{~h}$ with the yield of diamantane (1) being retained $(62 \%)$.

In order to answer the question of what is the hydrogen source in the hydroisomerization of binor- $\mathrm{S}\left(\mathrm{C}_{14} \mathrm{H}_{16}, 2\right)$ containing 4 hydrogen atoms less than diamantane $\left(\mathrm{C}_{14} \mathrm{H}_{20}, \mathbf{1}\right)$, we carried out a series of control experiments using deuterated sulfuric acid $(98 \%)$ in cyclohexane $\left(\mathrm{C}_{6} \mathrm{H}_{12}\right.$, experiment $\left.\mathrm{A}\right)$, in deuterated cyclohexane $\left(\mathrm{C}_{6} \mathrm{D}_{12}\right.$, experiment $\left.\mathrm{B}\right)$, or in carbon disulfide $\left(\mathrm{CS}_{2}\right.$, experiment $\left.\mathrm{C}\right)$.

In experiment $\mathbf{A}$, the major isomer $\mathbf{1}-\mathbf{D}_{\mathbf{2}}$, which is formed upon hydroisomerization of binor-S (2), contains two deuterium atoms. Two more hydrogen atoms are probably provided by cyclohexane. Unexpectedly, the reaction also gave undeuterated diamantane (1), which may be due to deuterium exchange with hydrogen of cyclohexane under the action of $\mathrm{D}_{2} \mathrm{SO}_{4}$.

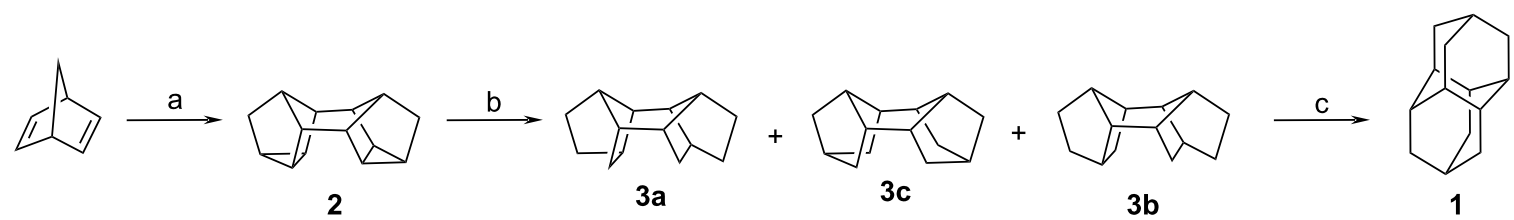

Scheme 1: Isomerization of 3a-c to diamantane (1). Reaction conditions: (a) $\mathrm{CoBr}_{2} \cdot 2 \mathrm{PPh}_{3}-\mathrm{BF}_{3} \cdot \mathrm{OEt}_{2}, 110{ }^{\circ} \mathrm{C}, 12 \mathrm{~h}$; (b) $\mathrm{Pt}, \mathrm{H}_{2}(200 \mathrm{psi}), 70{ }^{\circ} \mathrm{C}, 3 \mathrm{~h}$; (c) superacidic catalysts or $\mathrm{NaY}-\mathrm{NaH}$.

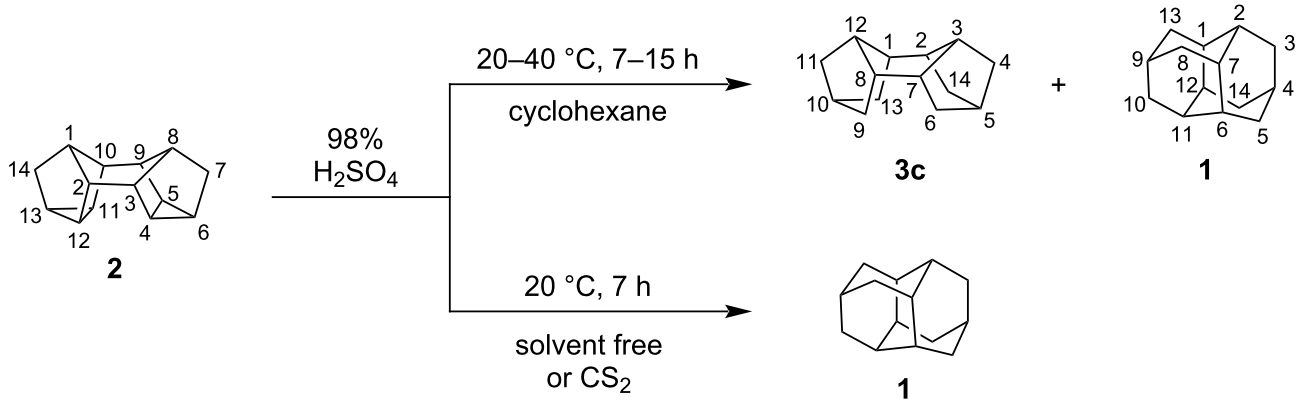

Scheme 2: Isomerization of binor-S (2) to diamantane (1). 


\begin{tabular}{|c|c|c|c|c|c|c|c|}
\hline \multirow[t]{2}{*}{ entry } & \multirow{2}{*}{$\begin{array}{l}\text { ratio } \\
{[2] /\left[\mathrm{H}_{2} \mathrm{SO}_{4}\right]}\end{array}$} & \multirow[t]{2}{*}{ solvent } & \multirow[t]{2}{*}{ temp. $\left[{ }^{\circ} \mathrm{C}\right]$} & \multirow[t]{2}{*}{ time [h] } & \multicolumn{3}{|c|}{ product ratio [\%] } \\
\hline & & & & & 2 & 3 & 1 \\
\hline 1 & $1: 50$ & cyclohexane & 40 & 7 & 2 & 10 & 23 \\
\hline 2 & $1: 50$ & cyclohexane & 20 & 7 & 3 & 26 & 10 \\
\hline 3 & $1: 20$ & cyclohexane & 40 & 7 & 3 & 52 & 28 \\
\hline 4 & $1: 20$ & cyclohexane & 20 & 7 & 12 & 46 & 22 \\
\hline 5 & $1: 20$ & cyclohexane & 20 & 15 & - & 55 & 31 \\
\hline 6 & $1: 10$ & cyclohexane & 20 & 7 & 22 & 41 & 36 \\
\hline 7 & $1: 10$ & cyclohexane & 20 & 15 & 16 & 47 & 34 \\
\hline 8 & $1: 5$ & cyclohexane & 40 & 15 & 56 & 31 & 2 \\
\hline 9 & $1: 20$ & carbon disulfide & 20 & 7 & 21 & - & 36 \\
\hline 10 & $1: 20$ & carbon disulfide & 20 & 15 & 15 & - & 44 \\
\hline 11 & 1:10 & carbon disulfide & 20 & 7 & 24 & - & 52 \\
\hline 12 & $1: 10$ & carbon disulfide & 20 & 15 & - & - & 65 \\
\hline 13 & $1: 5$ & carbon disulfide & 40 & 7 & 78 & - & 10 \\
\hline 14 & $1: 5$ & carbon disulfide & 20 & 7 & 90 & - & - \\
\hline 15 & $1: 10$ & - & 20 & 7 & - & - & 8 \\
\hline $16^{\mathrm{b}}$ & $1: 10$ & cyclohexane & 20 & 2 & 9 & 64 & 26 \\
\hline $17^{\mathrm{b}}$ & $1: 10$ & carbon disulfide & 20 & 2 & - & 18 & 62 \\
\hline $18^{b}$ & $1: 10$ & - & 20 & 2 & - & - & 6 \\
\hline
\end{tabular}

aDetermined by $\mathrm{GC}$ using $\mathrm{C}_{12} \mathrm{H}_{26}$ as the internal standard. ${ }^{\mathrm{b}}$ The reaction was conducted under ultrasonic irradiation.

The major product $\mathbf{1}-\mathbf{D}_{\mathbf{3}}$, which is formed in experiment $\mathrm{B}$ with $\mathrm{D}_{2} \mathrm{SO}_{4}$ in $\mathrm{C}_{6} \mathrm{D}_{12}$ contains three deuterium atoms. The expected isomer with four deuterium atoms is formed in a minor amount. Evidently, binor-S (2) acts as the hydrogen source for the isomer $\mathrm{C}_{14} \mathrm{H}_{17} \mathrm{D}_{3}, \mathbf{1}-\mathbf{D}_{\mathbf{3}}$. Our attempt to carry out the deuteration of diamantane (1) with $\mathrm{D}_{2} \mathrm{SO}_{4}$ in carbon disulfide for $7 \mathrm{~h}$ at $20{ }^{\circ} \mathrm{C}$ was unsuccessful. Evidently, the deuterium exchange, resulting in the formation of diamantanes $\mathbf{1}-\mathbf{D}_{\mathbf{7}}$ and $\mathbf{1}-\mathbf{D}_{\mathbf{8}}$ containing 7 and 8 deuterium atoms, occurs at the hydroisomerization step (experiment C).

As shown by further studies, when the sulfuric acid concentration decreases to $75-80 \%$, the reaction stops at the intermediate step giving endo-endo-pentacyclo[7.3.1.1 $\left.1^{2,5} \cdot 1^{8,10} \cdot 0^{3,7}\right]$ tetradecane (tetrahydrobinor-S, 3c; Scheme 3). It should be emphasized that the reaction selectively gives only one of the possible isomers, hydrocarbon $\mathbf{3 c}$, which is confirmed by ${ }^{1} \mathrm{H}$ and ${ }^{13} \mathrm{C}$ NMR spectral data. The ${ }^{13} \mathrm{C}$ NMR spectrum of compound 3c shows five characteristic carbon signals at 33.44, 35.64, $37.84,38.30$, and $40.49 \mathrm{ppm}$, coinciding with the reported values [13]. Since $75-80 \% \mathrm{H}_{2} \mathrm{SO}_{4}$ contains $20-25 \%$ water, the participation of water as a hydrogen source in the reaction cannot be ruled out either.

Attempts to perform hydroisomerization of binor-S (2) to diamantane (1) on treatment with nitric or orthophosphoric acid

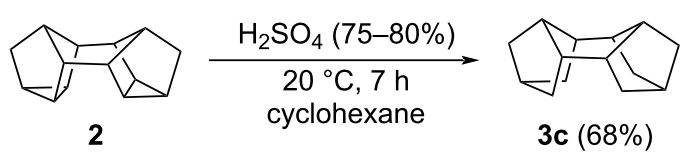

Scheme 3: Selective synthesis of tetrahydrobinor-S (3c) from binor-S (2).

were unsuccessful, with the starting binor-S (2) being recovered unchanged. The reaction of hydrocarbon $\mathbf{2}$ with hydrochloric acid proceeds with the addition of $\mathrm{HCl}$ to the cyclopropane ring and results in the formation of a mixture of monoand dichloro derivatives, the synthesis of which has been reported $[13,14]$. When sulfuric acid is replaced by an ionic liquid prepared from triethylamine and sulfuric acid [15], the reaction follows a different route: Starting binor-S (2) is converted to two isomeric hexacyclic hydrocarbons, hexacyclo[8.4.0.0 $\left.0^{2,7} \cdot 0^{3,14} \cdot 0^{4,8} \cdot 0^{9,13}\right]$ tetradec-5-ene (4a) and hexacyclo[6.6.0.0..$\left.^{2,6} \cdot 0^{5,14} \cdot 0^{7,12} \cdot 0^{9,13}\right]$ tetradec-3-ene $(\mathbf{4 b})$, which are important precursors for the synthesis of triamantane $[10,11,16$ 24] (Scheme 4).

\section{Conclusion}

Thus, we developed a new one-pot method for the synthesis of diamantane (1) by hydroisomerization of binor-S (2) on treatment with concentrated sulfuric acid $(98 \%)$ in carbon disulfide 


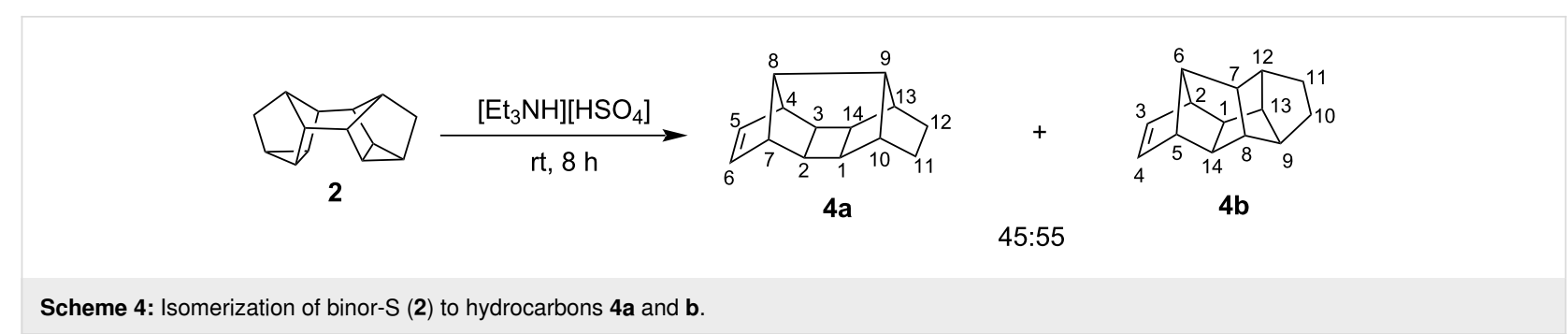

or cyclohexane. It was found that both, sulfuric acid and cyclohexane can serve as the main hydrogen sources. In the presence of $\mathrm{H}_{2} \mathrm{SO}_{4}$ with a lower concentration $(75-80 \%)$, the reaction stops at the step of formation of endo-endo-pentacyclo[7.3.1.1 $\left.1^{2,5} \cdot 1^{8,10} \cdot 0^{3,7}\right]$ tetradecane $(\mathbf{3 c})$ in $68 \%$ yield.

\section{Experimental}

General procedures and materials: ${ }^{1} \mathrm{H}$ and ${ }^{13} \mathrm{C}$ NMR spectra were measured on a Bruker Avance-III 400 Ascend instrument (400 MHz for ${ }^{1} \mathrm{H}$ and $100 \mathrm{MHz}$ for ${ }^{13} \mathrm{C}$ in $\mathrm{CDCl}_{3}$ ). Mass spectra were run on a Shimadzu GCMS-QP2010Plus mass spectrometer (SPB-5 capillary column, $30 \mathrm{~m} \times 0.25 \mathrm{~mm}$, helium as the carrier gas, temperature programming from 40 to $300{ }^{\circ} \mathrm{C}$ at $8{ }^{\circ} \mathrm{C} / \mathrm{min}$, evaporation temperature of $280^{\circ} \mathrm{C}$, ion source temperature of $200{ }^{\circ} \mathrm{C}$, and ionization energy of $70 \mathrm{eV}$ ). The elemental composition of the samples was determined on a Carlo Erba 1106 elemental analyzer. The course of the reaction and the purity of the products were monitored by gas liquid chromatography on a Shimadzu GC-9A, GC-2014 instrument [ $2 \mathrm{~m} \times 3 \mathrm{~mm}$ column, SE-30 silicone $(5 \%)$ on Chromaton $\mathrm{N}$-AW-HMDS as the stationary phase, temperature programming from 50 to $270{ }^{\circ} \mathrm{C}$ at $8{ }^{\circ} \mathrm{C} / \mathrm{min}$, helium as the carrier gas $(47 \mathrm{~mL} / \mathrm{min})]$.

The sonication was carried out with an ultrasound generator IL10-0.63 (INLAB LTD) for $180 \mathrm{~min}$ at a frequency of $22 \mathrm{kHz}$ with a submerged $15 \mathrm{~mm}$ diameter titanium horn, with output power $150 \mathrm{~W}$. The reactions were carried out in a $100 \times 35 \mathrm{~mm}$ glass reactor equipped with a jacket to maintain the required temperature $\left(20^{\circ} \mathrm{C}\right)$.

Preparation of diamantane: Heptacyclo[8.4.0.0 $\left.0^{2,12} \cdot 0^{3,8} \cdot 0^{4,6} \cdot 0^{5,9} \cdot 0^{11,13}\right]$ tetradecane $(2,0.368 \mathrm{~g}$, $2 \mathrm{mmol})$ and the solvent were charged into a glass reactor $(V=100 \mathrm{~mL})$. Then, concentrated (98\%) sulfuric acid (1.96 g, $20 \mathrm{mmol}$ ) was added in portions with vigorous stirring. When the whole amount of $\mathrm{H}_{2} \mathrm{SO}_{4}$ has been added, the reaction mixture was stirred at $20{ }^{\circ} \mathrm{C}$ for $15 \mathrm{~h}$. After completion of the reaction, $10 \% \mathrm{NaOH}$ was added to the reaction mixture, the organic phase was separated, and filtered through a silica gel layer (with petroleum ether as the eluent). The solvent was distilled off and the residue was recrystallized from a
1:1 ethyl acetate/cyclohexane mixture. The characteristic data and graphical spectra of diamantane are almost identical with the literature data [25].

Preparation of endo-endo-pentacyclo[7.3.1.1 $\left.{ }^{2,5} \cdot 1^{8,10} \cdot 0^{3,7}\right]$ tetradecane (tetrahydrobinor-S, 3c): Heptacyclo[8.4.0.0 $\left.0^{2,12} \cdot 0^{3,8} \cdot 0^{4,6} \cdot 0^{5,9} \cdot 0^{11,13}\right]$ tetradecane $(\mathbf{2}$, $0.368 \mathrm{~g}, 2 \mathrm{mmol})$ was charged into a glass reactor $(V=100 \mathrm{~mL})$ and dissolved in cyclohexane $(10 \mathrm{~mL})$. Then, $75-80 \%$ sulfuric acid $(1.96 \mathrm{~g}, 20 \mathrm{mmol})$ was added in portions with vigorous stirring. When the whole amount of $\mathrm{H}_{2} \mathrm{SO}_{4}$ has been added, the reaction mixture was stirred at $20^{\circ} \mathrm{C}$ for $7 \mathrm{~h}$. After completion of the reaction, $10 \% \mathrm{NaOH}$ was added to the reaction mixture, the organic part was separated, and filtered through a silica gel layer (with petroleum ether as the eluent). The solvent was distilled off and the residue was recrystallized from a 1:1 ethyl acetate/cyclohexane mixture. Colorless crystals; $68 \%$ yield; mp 104-106 ${ }^{\circ} \mathrm{C} ;{ }^{1} \mathrm{H}$ NMR $\left(400 \mathrm{MHz}, \mathrm{CDCl}_{3}\right) \delta$ 0.95-0.98 (m, 4H), $1.38(\mathrm{~s}, 8 \mathrm{H}), 1.66-1.71(\mathrm{~m}, 4 \mathrm{H}), 1.99-2.01$ (m, 2H), 2.12-2.16 (m, 2H); ${ }^{13} \mathrm{C}$ NMR $\left(100 \mathrm{MHz}, \mathrm{CDCl}_{3}\right) \delta$ $33.42\left(\mathrm{C}^{6}, \mathrm{C}^{9}, \mathrm{C}^{13}, \mathrm{C}^{14}\right), 35.63\left(\mathrm{C}^{1}, \mathrm{C}^{2}, \mathrm{C}^{7}, \mathrm{C}^{8}\right), 37.82\left(\mathrm{C}^{5}\right.$, $\left.\mathrm{C}^{10}\right), 38.27\left(\mathrm{C}^{3}, \mathrm{C}^{12}\right), 40.47\left(\mathrm{C}^{4}, \mathrm{C}^{11}\right)$; EIMS $(70 \mathrm{eV}, \mathrm{m} / \mathrm{z}): 188$ $[\mathrm{M}]^{+}$(100), 187 (35), 159 (24), 145 (23), 131 (38), 117 (25), 105 (39), 91(82), 79 (57), 67 (29), 41 (47) \%; Anal. calcd for $\mathrm{C}_{14} \mathrm{H}_{20}$ : C, 89.29; H, 10.71; found: C, 89.14; H, 10.86.

Preparation of hexacyclo $\left[8.4 .0 .0^{2,7} \cdot 0^{3,14} .0^{4,8} .0^{9,13}\right]$ tetradec5-ene (4a) and hexacyclo[6.6.0.0. $\left.{ }^{2,6} .0^{5,14} .0^{7,12} .0^{9,13}\right]$ tetradec3-ene (4b): Heptacyclo[8.4.0.0 $\left.0^{2,12} \cdot 0^{3,8} \cdot 0^{4,6} \cdot 0^{5,9} \cdot 0^{11,13}\right]$ tetradecane $(2,0.368 \mathrm{~g}, 2 \mathrm{mmol})$ was charged into a glass reactor $(V=100 \mathrm{~mL})$ and dissolved in cyclohexane. Then, $\left[\mathrm{Et}_{3} \mathrm{NH}\right]^{+}\left[\mathrm{HSO}_{4}\right]^{-}(1.99 \mathrm{~g}, 10 \mathrm{mmol})$ was added and the reaction mixture was stirred at $40{ }^{\circ} \mathrm{C}$ for $8 \mathrm{~h}$. Then the reactor was cooled to room temperature, the reaction mixture extracted with petroleum ether, and filtered through a silica gel layer (with petroleum ether as the eluent). Hexacyclo[8.4.0.0 $\left.0^{2,7} \cdot 0^{3,14} \cdot 0^{4,8} \cdot 0^{9,13}\right]$ tetradec-5-ene (4a) and hexacyclo[6.6.0.0. $\left.{ }^{2,6} \cdot 0^{5,14} \cdot 0^{7,12} \cdot 0^{9,13}\right]$ tetradec-3-ene (4b) (45:55). Colorless oil; 78\% yield; 4a: ${ }^{1} \mathrm{H}$ NMR $\left(400 \mathrm{MHz}, \mathrm{CDCl}_{3}\right) \delta$ $1.04(\mathrm{~d}, J=7.2 \mathrm{~Hz}, 2 \mathrm{H}), 1.41(\mathrm{~d}, J=7.6 \mathrm{~Hz}, 2 \mathrm{H}), 1.95(\mathrm{~s}, 2 \mathrm{H})$, $2.09(\mathrm{~d}, J=7.2 \mathrm{~Hz}, 4 \mathrm{H}), 2.21(\mathrm{~d}, J=7.2 \mathrm{~Hz}, 2 \mathrm{H}) 2.56(\mathrm{~s}, 2 \mathrm{H})$, $5.87(\mathrm{~s}, 2 \mathrm{H}) ;{ }^{13} \mathrm{C} \mathrm{NMR}\left(100 \mathrm{MHz}, \mathrm{CDCl}_{3}\right) \delta 26.27\left(\mathrm{C}^{11}, \mathrm{C}^{12}\right)$, 
$34.62\left(\mathrm{C}^{10}, \mathrm{C}^{13}\right), 36.34\left(\mathrm{C}^{1}, \mathrm{C}^{14}\right), 37.27\left(\mathrm{C}^{2}, \mathrm{C}^{3}\right), 40.68\left(\mathrm{C}^{4}\right.$, $\left.\mathrm{C}^{7}\right), 44.68\left(\mathrm{C}^{8}\right), 52.88\left(\mathrm{C}^{9}\right), 134.82\left(\mathrm{C}^{5}, \mathrm{C}^{6}\right)$; EIMS $(70 \mathrm{eV}$, $\mathrm{m} / \mathrm{z}): 184 \mathrm{[M}^{+}$(44), 169 (14), 155 (16), 142 (34), 117 (100), 115 (37), 105 (22), 91 (73), 80 (38), 65 (17), 41 (21) \%; 4b: ${ }^{1} \mathrm{H}$ NMR (400 MHz, $\mathrm{CDCl}_{3}$ ) $\delta 1.19-1.24(\mathrm{~m}, 1 \mathrm{H}), 1.31-1.36$ $(\mathrm{m}, 1 \mathrm{H}), 1.48(\mathrm{~s}, 1 \mathrm{H}), 1.56-1.59(\mathrm{~m}, 2 \mathrm{H}), 1.71(\mathrm{t}, J=6 \mathrm{~Hz}, 1 \mathrm{H})$ 2.03-2.06 (m, 3H), 2.15-2.17 (m, 2H), $2.22(\mathrm{~s}, 1 \mathrm{H}), 2.52(\mathrm{~s}$, 2H), 2.59 (s, 1H), 5.96-5.98 (m, 1H); ${ }^{13} \mathrm{C} \mathrm{NMR} \mathrm{(100} \mathrm{MHz,}$ $\left.\mathrm{CDCl}_{3}\right) \delta 24.08\left(\mathrm{C}^{10}\right), 27.16\left(\mathrm{C}^{11}\right), 40.52\left(\mathrm{C}^{1}\right), 40.93\left(\mathrm{C}^{12}\right)$, $42.30\left(\mathrm{C}^{14}\right), 45.66\left(\mathrm{C}^{9}\right), 47.38\left(\mathrm{C}^{2}\right), 47.94\left(\mathrm{C}^{13}\right), 48.61\left(\mathrm{C}^{7}\right)$, $50.20\left(C^{8}\right), 54.09\left(C^{5}\right), 60.05\left(C^{6}\right), 133.69\left(C^{4}\right), 133.75\left(C^{3}\right)$; EIMS (70 eV, m/z): $184\left[^{[M]^{+}}\right.$(40), 169 (21), 155 (45), 141 (45), 129 (51), 117 (100), 115 (53), 91 (88), 78 (43), 65 (21), 41 (20) $\%$.

\section{Supporting Information}

\section{Supporting Information File 1}

Experimental procedures, NMR, and mass spectral data. [https://www.beilstein-journals.org/bjoc/content/ supplementary/1860-5397-16-205-S1.pdf]

\section{Funding}

The results were obtained with the financial support of the Russian Ministry of Education and Science (project no. 201905-595-000-058) on unique equipment at the 'Agidel' Collective Usage Center (Ufa Federal Research Center, Russian Academy of Sciences), by the Scholarship of the President of the Russian Federation to young scientists and postgraduates (SP-1601.2018.1) and carried out within the RF state assignment, reg. no. AAAA-A19-119022290009-3.

\section{ORCID ${ }^{\circledR}$ iDs}

Rishat I. Aminov - https://orcid.org/0000-0001-5427-6350

Ravil I. Khusnutdinov - https://orcid.org/0000-0003-1151-5248

\section{Preprint}

A non-peer-reviewed version of this article has been previously published as a preprint: https://doi.org/10.3762/bxiv.2020.85.v1

\section{References}

1. Murray, R. K.; Morgan, T. K.; Babiak, K. A. J. Org. Chem. 1975, 40, 1079-1083. doi:10.1021/jo00896a019

2. Williams, V. Z., Jr.; von Ragué Schleyer, P.; Gleicher, G. J.; Rodewald, L. B. J. Am. Chem. Soc. 1966, 88, 3862-3863. doi:10.1021/ja00968a036

3. Mrowca, J. J.; Katz, T. J. J. Am. Chem. Soc. 1966, 88, 4012-4015. doi:10.1021/ja00969a021

4. Gund, T. M.; Osawa, E.; Williams, V. Z.; Schleyer, P. v. R. J. Org. Chem. 1974, 39, 2979-2987. doi:10.1021/jo00934a009
5. Aminov, R. I.; Khusnutdinov, R. I. Russ. J. Org. Chem. 2017, 53, 1881-1883. doi:10.1134/s107042801712017x

6. Gunchenko, P. A.; Novikovskii, A. A.; Byk, M. V.; Fokin, A. A. Russ. J. Org. Chem. 2014, 50, 1749-1754. doi:10.1134/s1070428014120057

7. Tureček, F.; Hanuš, V.; Sedmera, P.; Antropiusová, H.; Mach, K. Collect. Czech. Chem. Commun. 1981, 46, 1474-1485. doi:10.1135/cccc19811474

8. Gund, T. M.; Thielecke, W.; Schleyer, P. v. R. Org. Synth. 1973, 53, 30-34. doi:10.15227/orgsyn.053.0030

9. Dzhemilev, U. M.; Khusnutdinov, R. I.; Muslimov, Z. S.; Mazitov, M. F. Pet. Chem. 1996, 36, 507-512.

10. Farooq, O.; Farnia, S. M. F.; Stephenson, M.; Olah, G. A. J. Org. Chem. 1988, 53, 2840-2843. doi:10.1021/jo00247a035

11. Olah, G. A.; Wu, A.-h.; Farooq, O.; Prakash, G. K. S. J. Org. Chem. 1989, 54, 1450-1451. doi:10.1021/jo00267a042

12. Dzhemilev, U. M.; Khusnutdinov, R. I.; Kislitsina, K. S.; Kutepov, B. I.; Khazipova, A. N.; Travkina, O. S. Method of producing diamantane (pentacyclo[7,3,1,14,12,02,7,06,11]tetradecane). Russian Patent RU2459794C1, Aug 27, 2012.

13. Khusnutdinov, R. I.; Muslimov, Z. S.; Dzhemilev, U. M.; Nefedov, O. M. Russ. Chem. Bull. 1993, 42, 692-697. doi:10.1007/bf00704004

14. Dzhemilev, U. M.; Khusnutdinov, R. I.; Muslimov, Z. S.; Tolstikov, G. A.; Nefedov, O. M. Russ. Chem. Bull. 1991, 40, 236. doi:10.1007/bf00959680

15. Karimi-Jaberi, Z.; Masoudi, B.; Rahmani, A.; Alborzi, K. Polycyclic Aromat. Compd. 2020, 40, 99-107. doi:10.1080/10406638.2017.1363061

16. Schwertfeger, H.; Fokin, A. A.; Schreiner, P. R. Angew. Chem., Int. Ed. 2008, 47, 1022-1036. doi:10.1002/anie.200701684

17. Hollowood, F. S.; McKervey, M. A.; Hamilton, R.; Rooney, J. J. J. Org. Chem. 1980, 45, 4954-4958. doi:10.1021/jo01312a026

18. Kafka, Z.; Vodička, L.; Galík, V. Collect. Czech. Chem. Commun. 1982, 47, 286-289. doi:10.1135/cccc19820286

19. Kafka, Z.; Vodicka, L.

Sb. Vys. Sk. Chem.-Technol. Praze, D: Technol. Paliv 1985, 51, 247-255.

20. Kafka, Z. Sb. Vys. Sk. Chem.-Technol. Praze, D: Technol. Paliv 1991, 59, 79-90.

21. Kafka, Z.; Vodicka, L. Sb. Vys. Sk. Chem.-Technol. Praze, D: Technol. Paliv 1984, 49, 125-137.

22. Kafka, Z.; Nahunek, M. Sb. Vys. Sk. Chem.-Technol. Praze, D: Technol. Paliv 1986, 55 , 71-99.

23. Kafka, Z.; Vodicka, L. Sb. Vys. Sk. Chem.-Technol. Praze, D: Technol. Paliv 1986, 54, 65-74.

24. Khusnutdinov, R. I.; Mukminov, R. R.; Aminov, R. I.; Khalilov, L. M.; Mescheryakova, E. S.; Dzhemilev, U. M. Tetrahedron Lett. 2015, 56, 536-538. doi:10.1016/j.tetlet.2014.12.006

25. Aminov, R. I.; Akshieva, A. N.; Khusnutdinov, R. I. Catal. Commun. 2019, 130, 105756. doi:10.1016/j.catcom.2019.105756 


\section{License and Terms}

This is an Open Access article under the terms of the Creative Commons Attribution License (https://creativecommons.org/licenses/by/4.0). Please note that the reuse, redistribution and reproduction in particular requires that the authors and source are credited.

The license is subject to the Beilstein Journal of Organic Chemistry terms and conditions:

(https://www.beilstein-journals.org/bjoc)

The definitive version of this article is the electronic one which can be found at:

https://doi.org/10.3762/bjoc.16.205 